\title{
Can we make stroke during cardiac surgery a never event?
}

\author{
Michael Mack, MD
}

See related article on pages 175-80 in the January 2015 issue.

Stroke has been and continues to be the Achilles heel of cardiac surgery. Periprocedural neurologic events during cardiac surgery remain prevalent, with stroke reported in $2.0 \%$ to $4.6 \%$ of patients undergoing cardiac surgery and increasing to at least $12.8 \%$ in octogenarians. ${ }^{1-3}$ The fear of stroke or other adverse neurologic outcomes, including so-called pump head, is a deterrent for patients to undergo the otherwise successful, life-saving operations that we perform. The interpretation of the SYNTAX trial "that with coronary artery bypass grafting (CABG) the patient is trading a 3 times higher risk of stroke $(2.2 \%$ vs $0.6 \%$; $P=.003$ ) for an increased risk of repeat revascularization with percutaneous coronary intervention (PCI)" ${ }^{4}$ is a frequent refrain heard throughout the interventional cardiology community. This concern about comparative periprocedural stroke risk of CABG and PCI is further substantiated by a comparison of stroke rates in approximately 190,000 Medicare patients by Edwards and colleagues. ${ }^{5}$ The 30day stroke rate for CABG was 4 times higher than with PCI $(1.55 \%$ vs $0.37 \%)$. Furthermore, the incidence of stroke after CABG reported in the Society of Thoracic Surgeons (STS) Adult Cardiac Surgery Database has not decreased over the past 10 years. This raises the question: Can we lower the risk of stroke during CABG to that of PCI or less?

This question has been asked many times over the past few decades, but a positive answer has proven elusive with no clear benefits demonstrated with various interventions and modifications of surgical technique. There are many reasons why it has been difficult to determine the benefits of different options to decrease stroke risk. There are multiple factors implicated in causing stroke during and after $\mathrm{CABG}$, including preexisting carotid and cerebral vascular disease, use of cardiopulmonary bypass, perfusion pressure during the procedure, manipulation of the

\footnotetext{
From Baylor Scott \& White Health, Dallas, Tex.

Disclosures: Author has nothing to disclose with regard to commercial support.

Received for publication Nov 30, 2014; revisions received Dec 25, 2014; accepted for publication Dec 26, 2014; available ahead of print Feb 28, 2015.

Address for reprints: Michael Mack, MD, 1100 Allied Dr, Plano, TX 75075 (E-mail: jillian.clark@baylorhealth.edu).

J Thorac Cardiovasc Surg 2015;149:965-7

0022-5223/\$36.00

Copyright (c) 2015 by The American Association for Thoracic Surgery

http://dx.doi.org/10.1016/j.jtcvs.2014.12.072
}

ascending aorta, and postoperative atrial fibrillation being the most likely culprits. With a relatively low incidence of stroke, powering randomized trials to demonstrate benefit is prohibitive and registry-based assessment is plagued by inconsistency in definitions, underreporting, selection bias, and treatment variability.

The avoidance of cardiopulmonary bypass with off-pump CABG was 1 way proposed to reduce the risk of stroke. However, the role of off-pump CABG in reducing that risk has been mixed at best with recent, randomized trials not demonstrating any decrease in stroke. ${ }^{6,7}$ Moss and colleagues $^{8}$ shed some significant light on the causation and prevention of stroke during CABG in their recently published study. Moss and colleagues ${ }^{8}$ analyzed the outcomes of in 12,079 isolated CABG procedures over 11 years. Aortic manipulation was completely avoided by using in situ internal thoracic arteries for inflow in $1552 \mathrm{pa}-$ tients $(12.9 \%)$, a clampless facilitating device was used for proximal anastomoses in 1548 patients $(12.8 \%)$, and aortic clamping was used in 8979 patients $(74.3 \%)$. The overall incidence of stroke was $1.4 \%$, with an incidence of $0.6 \%$ in the no aortic touch group, $1.2 \%$ in the clampless facilitating device group, and $1.5 \%$ in the clamp group $\left(P<.01\right.$ for no touch vs clamp). As stated by Hammon ${ }^{9}$ in the accompanying editorial comment, despite a heavier burden of atherosclerotic disease in the ascending aorta, a no touch aortic technique can lower the perioperative stroke risk to that of PCI.

Using the same no aortic touch technique, Prapas and colleagues (personal communication, November 2014) using bilateral internal thoracic artery grafts off-pump in 3723 consecutive patients from 2001 to 2014 , demonstrated that the incidence of stroke during $\mathrm{CABG}$ was a virtually identical: $0.35 \%$.

So what is the takeaway message? From this and other evidence in the literature, I propose:

1. All patients undergoing CABG should also have epiaortic ultrasound to assess the ascending aorta for atherosclerotic disease. ${ }^{10}$

2. Avoiding any manipulation of the ascending aorta best minimizes the risk of stroke; this is done optimally by off-pump coronary bypass and use of in situ bilateral internal thoracic arteries. ${ }^{8}$

3. If a graft needs to be placed on the ascending aorta, a clampless technique for performing the proximal anastomosis(es) should be used. ${ }^{8}$

4. If cardiopulmonary bypass is used, a single complete crossclamp should be used rather than partial clamping. ${ }^{11}$ 
Although these principles apply to CABG, the risk of stroke during aortic valve replacement is a totally separate and perhaps even larger issue. In a study by Messé and colleagues, ${ }^{12}$ the Determining Neurologic Outcomes from Valve Operations Study, they determined that the clinical incidence of stroke after surgical aortic valve replacement was $17 \%$; the highest yet reported in the literature. ${ }^{12}$ The reason for such a high stroke rate was that a neurologist examined all patients preoperatively and performed serial postoperative neurologic exams. In the same group of patients, the incidence of stroke reported to the STS database was $7 \%$. Furthermore, $54 \%$ of the patients who did not experience a clinical stroke had evidence of cerebral emboli by diffusion-weighted magnetic resonance imaging (DWI). So it is evident that the harder you look, the more you find. With careful preoperative and serial postoperative neurologic assessment by a neurologist and routine use of DWI, the incidence of brain injury after surgical aortic valve replacement is much higher than reported in the STS database and previously reported in the literature. The significance of subclinical lesions detected by imaging is not known, but there is increasing evidence that cerebral embolic burden is associated with late neurocognitive decline. ${ }^{13}$ To emphasize the importance of lesions detected on DWI without clear clinical findings, the new American Heart Association/American Stroke Association statement ${ }^{14}$ has modified the definition currently used in the STS database and most recent clinical trials. Stroke is now defined as "a central nervous system infarction defined as brain, spinal cord, or retinal cell death attributable to ischemia, based on neuropathological, neuroimaging, and/ or clinical evidence of permanent injury." ${ }^{14}$ In other words, lesions found on DWI count as strokes even in the absence of obvious clinical findings. As this new definition is more widely adopted and standardized, the reported incidence of brain injury during cardiac surgery can be expected to increase.

The importance of brain injury during surgical aortic valve replacement and transcatheter aortic valve replacement has stimulated intense interest in the field of cerebral embolic protection. Cerebral protection devices fall into 2 broad categories: embolic capture and embolic deflection. A recent study ${ }^{15}$ using a capture device for emboli during transthoracic aortic valve replacement, the Montage Cerebral Protection System (Claret Medical, Santa Rosa, Calif) has been shown to decrease embolic load demonstrated by DWI to protected areas of the brain by $60 \%$ and decrease the incidence of clinical ataxia from $24 \%$ to $9 \%$. A small study of 15 patients undergoing transthoracic aortic valve replacement with a deflection device, the Embrella (Edwards Lifesciences, Irvine, Calif), ${ }^{16}$ showed a decrease in cerebral embolic lesion volume but not compared with historical controls. There are currently 2 devices with the potential to decrease cerebral emboli after surgical aortic valve replacement. The Embol-X device (Edwards Lifesciences, Irvine, Calif) is a filter designed to capture emboli that is placed in the ascending aorta during placement and removal of the aortic crossclamp. ${ }^{17}$ The safety and efficacy of this device will be studied in a randomized trial of 330 patients in the Cardiothoracic Surgery Network sponsored by the National Heart, Lung, and Blood Institute. A second device with a totally different concept, the Cardiogard Cannula, (Cardiogard Medical, Ltd, Or Yehuda, Israel) has a suction side port attached to the aortic cannula that creates a vortex at the cannula tip thereby removing the majority of both solid and gaseous emboli. It has demonstrated efficacy in a small randomized trial and will likely start randomized trials in the United States soon. ${ }^{18}$ The importance of preventing adverse neurologic outcomes after surgical and catheter-based procedures is highlighted by the fact that preliminary discussions have occurred between multiple stakeholders in the field, including the National Heart, Lung, and Blood Institute-sponsored Cardiothoracic Surgery Network and the STS/American College of Cardiology Transcatheter Valve Therapy registry to set up a network of study sites with expertise in neurologic outcomes assessment capable of performing randomized trials using a registry infrastructure.

The issue of stroke during cardiac surgery and transthoracic aortic valve replacement cannot be ignored. The consequences of brain injury are both acute and long-term. As we become more informed as to how to detect injury, including careful examinations by neurologists and broader use of DWI, the magnitude of the problem will become even more apparent. It behooves us to adopt the techniques for CABG that have demonstrated benefit; that is, "Don't touch that aorta." The light in the field of transthoracic aortic valve replacement is now focused on mechanisms to prevent brain injury by cerebral embolic protection. We need the same focus with surgical aortic valve replacement to minimize this risk. We can serve our patients better by making a concerted effort to make stroke and brain injury never events during all cardiac operations.

\section{References}

1. Ngaage DL, Cowen ME, Griffin S, Guvendik L, Cale AR. Early neurological complications after coronary artery bypass grafting and valve surgery in octogenarians. Eur J Cardiothorac Surg. 2008;33:653-9.

2. Bucerius J, Gummert JF, Borger MA, Walther T, Doll N, Onnasch JF, et al. Stroke after cardiac surgery: a risk factor analysis of 16,184 consecutive adult patients. Ann Thorac Surg. 2003;75:472-8.

3. Mérie C, Køber L, Olsen PS, Andersson C, Jensen JS, Torp-Pederson C. Risk of stroke after coronary artery bypass grafting: effect of age and comorbidities. Stroke. 2012;43:38-43.

4. Serruys PW, Morice MC, Kappetein AP, Colombo A, Holmes DR, Mack MJ, et al. Percutaneous coronary intervention versus coronary-artery bypass grafting for severe coronary artery disease. N Engl J Med. 2009; 360:961-72.

5. Edwards FH, Shahian DM, Grau-Sepulveda MV, Grover F, Mayer JE, O'Brien SM, et al. Composite outcomes in coronary bypass surgery versus percutaneous Intervention. Ann Thorac Surg. 2014;97:1983-90. 
6. Diegeler A, Börgermann J, Kappert U, Breuer M, Boning A, Ursulescu A, et al. Off-pump versus on-pump coronary-artery bypass grafting in elderly patients. $N$ Engl J Med. 2013;368:1189-98.

7. Lamy A, Devereaux PJ, Prabhakaran D, Taggart DP, Shengshou H, Paolasso E, et al. Off pump or on pump coronary artery bypass grafting at 30 days. $N$ Engl $J$ Med. 2012;366:1489-97.

8. Moss E, Puskas JD, Thourani VH, Kilgo P, Chen EP, Leshnower BG, et al. Avoiding aortic clamping during CABG reduces postoperative stroke. J Thorac Cardiovasc Surg. 2015;149:175-80.

9. Hammon J. Don't touch that aorta! J Thorac Cardiovasc Surg. 2015;149: $180-1$.

10. Rosenberger P, Shernan SK, Löffler M, Shekar PS, Fox JA, Tuli JK, et al. The influence of epiaortic ultrasonography on intraoperative surgical management in 6051 cardiac surgical patients. Ann Thorac Surg. 2008;85:548-53.

11. Hammon JW, Stump DA, Butterworth JF, Moody DM, Rorie K, Deal DD, et al. Coronary artery bypass grafting with single cross-clamp results in fewer persistent neuropsychological deficits than multiple clamp or off-pump coronary artery bypass grafting. Ann Thorac Surg. 2007;84:1174-8; discussion 1178-9.

12. Messé SR, Acker MA, Kasner SE, Fanning M, Giovannetti T, Ratcliffe SJ, et al. Determining Neurologic Outcome From Valve Operations (DeNOVO) investigators. Stroke after aortic valve surgery: results from a prospective cohort. Circulation. 2014;129:2253-61.
13. Barber PA, Hach S, Tippett L, Ross L, Merry AF, Milsom P. Cerebral ischemic lesions on diffusion-weighted imaging are associated with neurocognitive decline after cardiac surgery. Stroke. 2008;39:1427-33.

14. Sacco RL, Kasner SE, Broderick JP, Caplan LR, Connors JJ, Culebras A, et al. An updated definition of stroke for the 21st century: a statement for healthcare professionals from the American Heart Association/American Stroke Association. Stroke. 2013;44:2064-89.

15. Linke A, Haussig S, Dwyer MG, Mangner M, Lemkuhl L, Lucke L, et al. A prospective, randomized trial of cerebral embolic protection in high risk patients with aortic stenosis undergoing transcatheter aortic valve replacement. Presented at Transthoracic Cardiovascular Therapeutics 2014, September 13-17, 2014, Washington, DC

16. Samim M, Agostoni P, Hendrikse J, Budde RP, Nijhoff F, Kluin J, et al. Embrella embolic deflection device for cerebral protection during transcatheter aortic valve replacement. J Thorac Cardiovasc Surg. 2015;149:799-805.e2.

17. Banbury MK, Kouchoukos NT, Allen KB, Slaughter M, Weissman NJ, Berry GJ, et al. Emboli capture using the Embol-X intraaortic filter in cardiac surgery: a multicentered randomized trial of 1,289 patients. Ann Thorac Surg. 2003;76: 508-15; discussion 515.

18. Bolotin G, Huber CH, Shani L, Mohr FW, Carrel TP, Borger MA, et al. Novel emboli protection system during cardiac surgery: a multicenter, randomized, clinical trial. Ann Thorac Surg. 2014;98:1627-34.

Access to The Journal of Thoracic and Cardiovascular Surgery Online is reserved for print subscribers!

Full-text access to The Journal of Thoracic and Cardiovascular Surgery Online is available for all print subscribers. To activate your individual online subscription, please visit The Journal of Thoracic and Cardiovascular Surgery Online, point your browser to http://www.mosby.com/jtcvs, follow the prompts to activate your online access, and follow the instructions. To activate your account, you will need your subscriber account number, which you can find on your mailing label (note: the number of digits in your subscriber account number varies from 6 to 10 ). See the example below in which the subscriber account number has been circled:

\section{Sample mailing label}

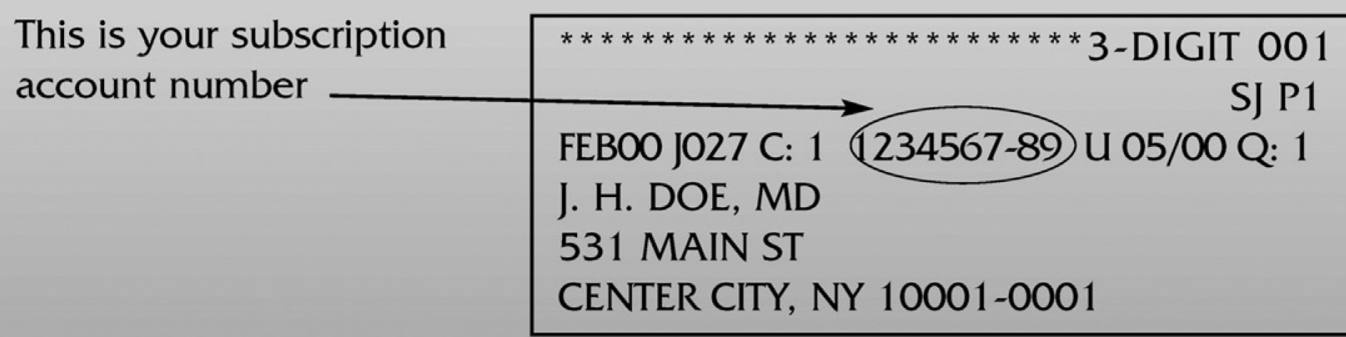

Personal subscriptions to The Journal of Thoracic and Cardiovascular Surgery Online are for individual use only and may not be transferred. Use of The Journal of Thoracic and Cardiovascular Surgery Online is subject to agreement to the terms and conditions as indicated online. 